\title{
Multiple metastases of bones and sigmoid colon after mastectomy for ductal carcinoma in situ of the breast: a case report
}

Qiuting You, ${ }^{1,2}$, Yichao Fang ${ }^{1,2}$, Chenchen Li ${ }^{1,3}$, Yujie Tan ${ }^{1,3}$, Jianli Zhao ${ }^{1,2}$, Cui Tan ${ }^{1,4}$, Ying Wang ${ }^{1,2}$, Herui $\mathrm{YaO}^{1,2,3^{*}}$ and Fengxi Su${ }^{1,2^{*}}$

\begin{abstract}
Background: The prognosis of ductal carcinoma in situ (DCIS) is reportedly well. Extremely rare patients with DCIS develop distant breast cancer metastasis without locoregional or contralateral recurrence. This is the first report of multiple bones and sigmoid colon metastases from DCIS after mastectomy.

Case presentation: A 43-year-old woman was diagnosed with DCIS, and she received mastectomy, followed by endocrine therapy and target therapy. During the following-up, convulsions and pain on the legs were complaint. Therefore, Computed Tomography (CT) on bones and positron emission tomography (PET) for whole body were examined in order. Multiple bones and sigmoid colon were under the suspect of metastases, which were then verified by biopsy in the left ilium and colonoscopy respectively.

Conclusions: This case reveals the heterogeneous behavior and the potential poor outcome of DCIS, regular examination and surveillance are necessary even though the distant metastasis rate in DCIS is low.
\end{abstract}

Keywords: Ductal carcinoma in situ, Breast cancer, Distant metastasis, Metastasis of bone, Metastasis of sigmoid colon

\section{Background}

Rarely, patients with ductal carcinoma in situ (DCIS) developed distant breast cancer metastasis after mastectomy, the proportion has been reported to be far less than $1 \%[1$, 2]. Even rare are patients with DCIS developing distant metastasis $(\mathrm{DM})$ without preceding invasive locoregional or contralateral recurrence. Therefore, multiple breast cancer metastases of more than one organs after mastectomy for DCIS patients are extremely rare.

We now report our experience with a case of multiple metastases in bones and sigmoid colon after mastectomy for DCIS of the breast.

\footnotetext{
* Correspondence: yaoherui@163.com; sufengxi@mail.sysu.edu.cn ${ }^{1}$ Guangdong Provincial Key Laboratory of Malignant Tumor Epigenetics and Gene Regulation, Sun Yat-Sen Memorial Hospital, Sun Yat-Sen University, Guangzhou 510120, China

Full list of author information is available at the end of the article
}

\section{Case presentation}

In 2016, a unpalpable mass was discovered in a 43-yearold woman on the examination of ultrasound. Excisional biopsy revealed that it was a ductal carcinoma in situ of breast. Modified radical mastectomy for breast cancer was then performed for the patient in GUANGDONG GENERAL HOSPITAL in May 7th, 2016. The postoperative pathological diagnosis was high-grade ductal carcinoma in situ with microinvasion (the largest diameter of invasive region $<0.1 \mathrm{~cm}$ ), without any lymph nodes involvement. The DICS presented both positive for the estrogen receptor (ER) and progesterone receptor (PR), positive for human epidermal factor receptor 2 (HER2), with a $30 \%$ expression of Ki-67. The grade of breast cancer for the patient was characterized as pT1micN0M0.

Endocrine therapy and Target therapy were administered for the patient after surgery. Exemestane was consumed $25 \mathrm{mg} /$ day first, but it was replaced by letrozole

(C) The Author(s). 2019 Open Access This article is distributed under the terms of the Creative Commons Attribution 4.0 International License (http://creativecommons.org/licenses/by/4.0/), which permits unrestricted use, distribution, and 
on January 15th, 2018 due to the shortage of exemestane in Chinese pharmacy. Lapatinib was given $1000 \mathrm{mg} /$ day from June 2016 to June 2017 since a 50\% reduction in left ventricular ejection fraction indicting that Herceptin was not suitable on this occasion. Zoledronic acid was used to protect the bones and Leuprorelin was used to suppressed the ovarian function during the same period. On April 12th, 2018, an examination of Computed Tomography (CT) on bones was conducted under the patient's complaint of convulsions and pain on the legs, the sign of multiple bone metastases were found by the result of CT. Besides, nodes at right abdominal wall and right paracolic sulci region were also under the suspicion of metastases through a further examination by positron emission tomography (PET) (Fig. 1.). Multiple metastases were confirmed by pathological examination after biopsy in the left ilium under CT's guidance and in the sigmoid colon through colonoscopy (Fig. 2.).

The duration of disease-free survival of the patient was 1 year and 11 months. After the detection of multiple distant metastases, fulvestrant, anastrozole, Leuprorelin and Zoledronic acid were used at the same time to prevent the prognosis of metastatic breast cancer and the progression is stable now.

\section{Discussion and conclusions}

With the confinement of neoplastic lesion to the breast ducts, DCIS is usually precluded by the possibility of DM. Most DCIS patients developing DM had an intervening invasive locoregional recurrence, which was often taken for the prime culprit of the progress. Very rare DCIS patients developed DM and skipped the step of recurrence in former researches. For instance, only 6 of 814 patients developed DM as first event after the diagnosis of DCIS in the National Surgical Adjuvant Breast and Bowel Project B-17 trial [3]. Distant metastases to more than one organs after the initial treatment of DCIS has not been reported previously, this case in our experience is therefore an exception.

The factors associated with the development of DM in DCIS include younger age ( $<=40$ years), positive lymph nodes metastasis, microinvasion, necrosis, negative expression of estrogen receptor, poorly differentiation, preceding or simultaneous invasive locoregional recurrence

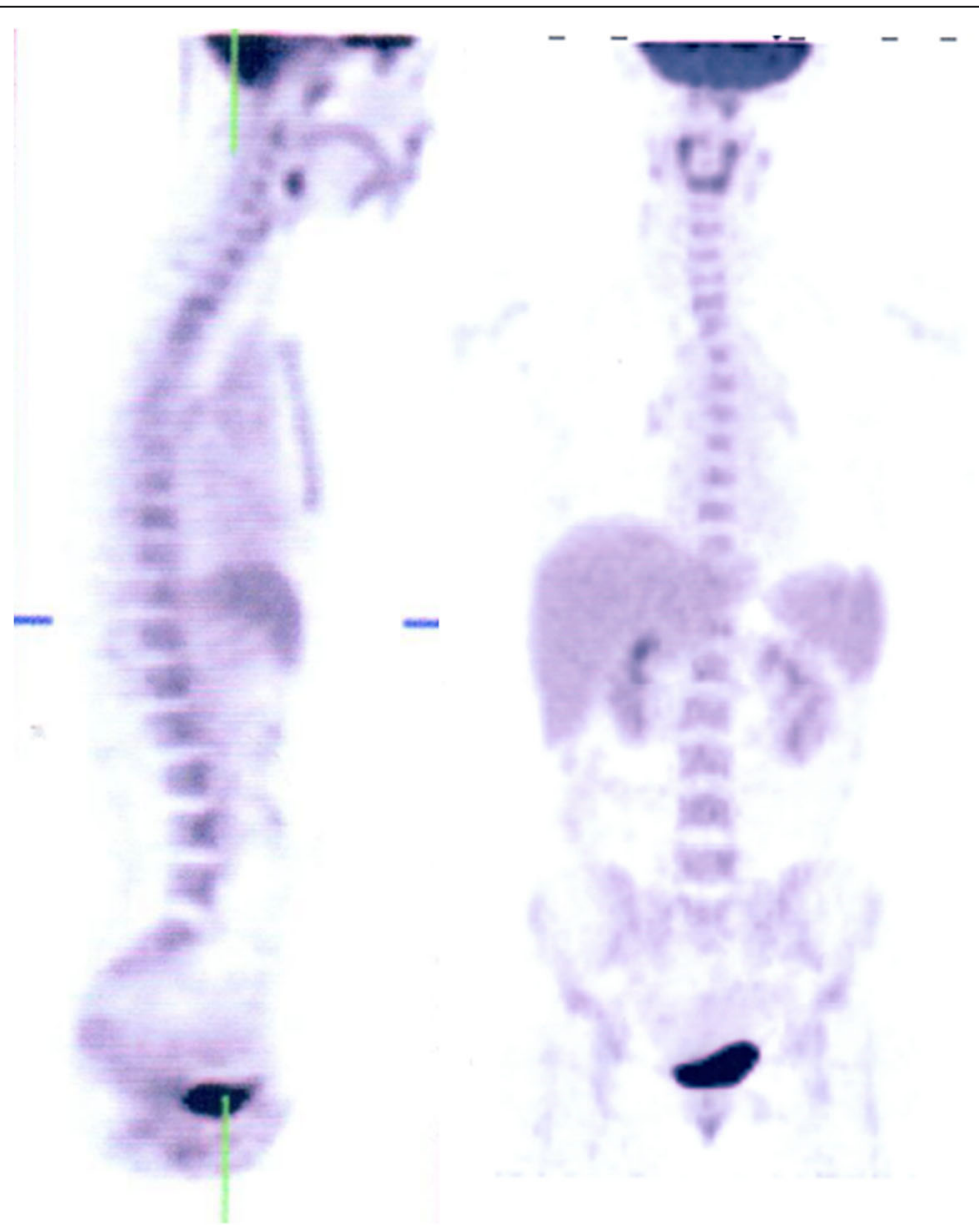

Fig. 1 PET/CT revealed abnormal accumulation of FDG in multiple sites in the bone 



Fig. 2 Biopsy of the left ilium at 200x magnification shows metastasis from breast carcinoma

$[2,4,5]$. Other prognostic pathological markers associated with invasive or noninvasive recurrence and distant metastasis involve positive Her2 expression, high Ki67 staining (>10\%), alone or co-expression [6, 7]. However, due to the small amount of cases with DM after DCIS, these factors didn't show a meaningful statistical significance in the published series. The presented risks in this case include poorly differentiation, microinvasion, positive Her2 expression, and high Ki67, but the connection between them and DM remains unknown.

DCIS with microinvasion (DCISMi) was defined as DCIS with foci of microinvasion (one or more foci of stromal invasion, none exceeding $0.1 \mathrm{~cm}$ in size) by AJCC (American Joint Committee on Cancer) cancer staging manual [8]. However, the interobserver variability of pathologists when assessing the breast specimens might be able to influence the staging and the histopathological features of DCIS $[9,10]$. Unnoticeable microinvasion or other histopathological markers might also be omitted or lower assessed in the cancer of this patient in our case.

In terms of pathological characteristics and prognosis, DCISMi resembles closer to stage I breast cancer rather than pure DCIS $[11,12]$. Some studies found that patients with microinvasion had a worse prognosis than patients with pure DCIS $[11,13,14]$. The cancer specific death rate for DCISMi patients in Surveillance, Epidemiology and End Results (SEER) database with more than 7 years following-up is $2.4 \%$, which was closer to that of $0.2-1.0 \mathrm{~cm}$ invasive breast cancer $(1.1 \%$ for pure DCIS, $2.4 \%$ for $0.2-1.0 \mathrm{~cm}$ invasive breast cancer) [11]. Therefore, more rigorous systematic therapy was performed in DCISMi. The rates of mastectomy, post-lumpectomy radiation and chemotherapy were higher for DCISMi than DCIS $(40.9,91.0,4.1 \%$ for DCISMi; 30.6, 80.6, 1.9\% for DCIS respectively) [12]. Chemotherapy was not recommended in the guideline of National Comprehensive Cancer Network (NCCN) [15] and the SSO-ASTROASCO DCIS Consensus, both for pure DCIS and DCISMi. However, still 4.1\% patients of DCISMi would be treated with chemotherapy, reflecting clinicians' special attention to the microinvasive portion in DCISMi. This case in our experience is also a warning sign for the potential malignant outcome of DCIS with microinvasion. To some extent, DCISMi should be regarded as invasive breast cancer instead of pure DCIS, the patients with DCISMi should be closely followed-up similar to invasive ductal cancer for the progression of DM.

Most frequent metastatic sites of breast cancer are lung, bone, liver and brain, and different pathological subtypes favor different organs. All the subtypes of breast cancer are inclined to bone metastases, especially in HR+/HER2- and HR+/HER2+ subtypes. The proportions of bone metastases in all DM are 58.52 and $47.28 \%$ for HR+/HER2- and HR+/HER2+ breast cancer respectively [16]. While this case in our center metastasizing to multiple bones seemed reasonable since the cancer was HR+/HER2+ subtype, the metastasis to sigmoid colon was quite unusual.

Metastasis to gastrointestinal tract was exceedingly rare for breast cancer and when it happened, sigmoid colon wasnot the most frequent sites for ductal carcinoma [17]. Cases of breast adenocarcinoma with colonic polyp metastasis and ductal carcinoma with scirrhous colonic metastasis had ever been reported in literature $[18,19]$. They partly represented the evidence of systemic spread for breast cancer, but no consensus on the metastatic mechanism and proper clinical management could be extracted due to the rarity of gastrointestinal involvement.

Bone metastases in this case were diagnosed by the clinical symptom of bone and joint pain. According to the outcomes in the TEXT (Tamoxifen and Exemestane Trial) and SOFT (Suppression of Ovarian Function Trial) randomized trials, worsening in bone or joint pain was more common in patients with aromatase inhibitor (AI) + ovarian function suppression (OFS) comparing with tamoxifen+ OFS [20]. The pain between bone metastases and side effects of endocrinotherapy is hard to distinguish. Part of the pain in metastatic bones and 
joints may be mistaken as side effects of AI. Therefore, auxiliary examination by $\mathrm{CT}$ and magnetic resonance (MR) is necessary when the clinical symptoms and physical examination could not tell the truth.

This case reveals the heterogeneous behavior and the potential poor outcome of DCIS, which need to be investigated further in the mechanism of metastasis. Tough the distant metastasis rate in DCIS patients is low, regular examination and surveillance in clinical practice are still necessary to detect the unusual event in time.

\section{Abbreviations}

Al: Aromatase inhibitor; CT: Computed Tomography; DCIS: Ductal carcinoma in situ; DCISMi: DCIS with microinvasion; DM: Distant metastasis; ER: Estrogen receptor; HER2: Human epidermal factor receptor 2; HR: Hormonal receptor; OFS: Ovarian function suppression; PET: Positron emission tomography; PR: Progesterone receptor; SOFT: Suppression of Ovarian Function Trial; TEXT: Tamoxifen and Exemestane Trial

\section{Acknowledgements}

None.

\section{Authors' contributions}

QTY: Analyzing the data, drafting and revising the work. YCF: Data acquisition and interpreting data. CCL: Data acquisition. YJT: Drafting part of the work. JLZ: Data acquisition. CT: Interpreting data. YW: Revising the work HRY: Summarizing the work. FXS: Designing the work. All authors read and approved the final manuscript.

\section{Funding}

None.

\section{Availability of data and materials}

Not applicable.

\section{Ethics approval and consent to participate}

Not applicable.

\section{Consent for publication}

We had obtained the patient's written consent for her personal and clinical details along with the identifying images to be published in this study.

\section{Competing interests}

The authors declare that they have no competing interests.

\section{Author details}

'Guangdong Provincial Key Laboratory of Malignant Tumor Epigenetics and Gene Regulation, Sun Yat-Sen Memorial Hospital, Sun Yat-Sen University, Guangzhou 510120, China. ${ }^{2}$ Breast Tumor Center, Sun Yat-Sen Memorial Hospital, Sun Yat-Sen University, 107 Yanjiang West Road, Guangzhou 510120, People's Republic of China. ${ }^{3}$ Oncology Department, Sun Yat-Sen Memorial Hospital, Sun Yat-Sen University, 107 Yanjiang West Road, Guangzhou 510120, People's Republic of China. ${ }^{4}$ Pathology Department, Sun Yat-Sen Memorial Hospital, Sun Yat-Sen University, Guangzhou 510120, China.

Received: 22 November 2018 Accepted: 18 August 2019 Published online: 28 August 2019

\section{References}

1. Meijnen P, Oldenburg HS, Peterse JL, Bartelink H, Rutgers EJ. Clinical outcome after selective treatment of patients diagnosed with ductal carcinoma in situ of the breast. Ann Surg Oncol. 2008;15(1):235-43.

2. Roses RE, Arun BK, Lari SA, Mittendorf EA, Lucci A, Hunt KK, Kuerer HM. Ductal carcinoma-in-situ of the breast with subsequent distant metastasis and death. Ann Surg Oncol. 2011;18(10):2873-8.
3. Fisher B, Dignam J, Wolmark N, Mamounas E, Costantino J, Poller W, Fisher ER, Wickerham DL, Deutsch M, Margolese R, Dimitrov N, Kavanah M. Lumpectomy and radiation therapy for the treatment of intraductal breast cancer: findings from National Surgical Adjuvant Breast and bowel project B-17. J Clin Oncol. 1998;16(2):441-52.

4. Yen TW, Hunt KK, Ross MI, Mirza NQ, Babiera GV, Meric-Bernstam F, Singletary SE, Symmans WF, Giordano SH, Feig BW, Ames FC, Kuerer HM. Predictors of invasive breast cancer in patients with an initial diagnosis of ductal carcinoma in situ: a guide to selective use of sentinel lymph node biopsy in management of ductal carcinoma in situ. J Am Coll Surg. 2005; 200(4):516-26.

5. Bijker N, Peterse JL, Duchateau L, Julien JP, Fentiman IS, Duval C, Di Palma S, Simony-Lafontaine J, de Mascarel I, van de Vijver MJ. Risk factors for recurrence and metastasis after breast-conserving therapy for ductal carcinoma-in-situ: analysis of European Organization for Research and Treatment of Cancer trial 10853. J Clin Oncol. 2001;19(8):2263-71.

6. Rakovitch E, Nofech-Mozes S, Hanna W, Narod S, Thiruchelvam D, Saskin R, Spayne J, Taylor C, Paszat L. HER2/neu and Ki-67 expression predict noninvasive recurrence following breast-conserving therapy for ductal carcinoma in situ. Br J Cancer. 2012;106(6):1160-5.

7. Davis JE, Nemesure B, Mehmood S, Nayi V, Burke S, Brzostek SR, Singh M. Her2 and Ki67 biomarkers predict recurrence of ductal carcinoma in situ. Appl Immunohistochem Mol Morphol. 2016;24(1):20-5.

8. Giuliano AE, Edge SB, Hortobagyi GN. Eighth edition of the AJCC Cancer staging manual: breast Cancer. Ann Surg Oncol. 2018;25(7): 1783-5.

9. Van Bockstal M, Baldewijns M, Colpaert C, Dano H, Floris G, Galant C, Lambein K, Peeters D, Van Renterghem S, Van Rompuy AS, Verbeke S, Verschuere S, Van Dorpe J. Dichotomous histopathological assessment of ductal carcinoma in situ of the breast results in substantial interobserver concordance. Histopathology. 2018;73(6):923-32.

10. Brunye $T$, Mercan $E$, Weaver $\mathrm{DL}$, Elmore JG. Accuracy is in the eyes of the pathologist: the visual interpretive process and diagnostic accuracy with digital whole slide images. J Biomed Inform. 2017;66:171-9.

11. Sopik V, Sun P, Narod SA. Impact of microinvasion on breast cancer mortality in women with ductal carcinoma in situ. Breast Cancer Res Treat. 2018;167(3):787-95.

12. Thomas A, Weigel RJ, Lynch CF, Spanheimer PM, Breitbach EK, Schroeder $M C$. Incidence, characteristics, and management of recently diagnosed, microscopically invasive breast cancer by receptor status: lowa SEER 2000 to 2013. Am J Surg. 2017;214(2):323-8.

13. Solin LJ, Fowble BL, Yeh IT, Kowalyshyn MJ, Schultz DJ, Weiss MC, Goodman RL. Microinvasive ductal carcinoma of the breast treated with breastconserving surgery and definitive irradiation. Int J Radiat Oncol Biol Phys. 1992;23(5):961-8.

14. de Mascarel I, MacGrogan G, Mathoulin-Pelissier S, Soubeyran I, Picot V, Coindre JM. Breast ductal carcinoma in situ with microinvasion: a definition supported by a long-term study of 1248 serially sectioned ductal carcinomas. Cancer. 2002;94(8):2134-42.

15. Gradishar WJ, Anderson BO, Balassanian R, Blair SL, Burstein HJ, Cyr A, Elias AD, Farrar WB, Forero A, Giordano SH, Goetz MP, Goldstein LJ, Isakoff SJ, Lyons J, Marcom PK, Mayer IA, McCormick B, Moran MS, O'Regan RM, Patel SA, Pierce L, Reed EC, Salerno KE, Schwartzberg LS, Sitapati A, Smith KL, Smith ML, Soliman H, Somlo G, Telli ML, Ward JH, Kumar R, Shead DA. Breast Cancer, version 4.2017, NCCN clinical practice guidelines in oncology. J Natl Compr Cancer Netw. 2018;16(3):310-20.

16. Wu Q, Li J, Zhu S, Wu J, Chen C, Liu Q, Wei W, Zhang Y, Sun S. Breast cancer subtypes predict the preferential site of distant metastases: a SEER based study. Oncotarget. 2017;8(17):27990-6.

17. Cervi G, Vettoretto N, Vinco A, Cervi E, Villanacci V, Grigolato P, Giulini SM. Rectal localization of metastatic lobular breast cancer: report of a case. Dis Colon Rectum. 2001;44(3):453-5.

18. Jafferbhoy S, Paterson H, Fineron P. Synchronous gist, colon and breast adenocarcinoma with double colonic polyp metastases. Int J Surg Case Rep. 2014;5(8):523-6.

19. Law WL, Chu KW. Scirrhous colonic metastasis from ductal carcinoma of the breast: report of a case. Dis Colon Rectum. 2003;46(10):1424-7.

20. Bernhard J, Luo W, Ribi K, Colleoni M, Burstein HJ, Tondini C, Pinotti G, Spazzapan S, Ruhstaller T, Puglisi F, Pavesi L, Parmar V, Regan MM, Pagani O, Fleming GF, Francis PA, Price KN, Coates AS, Gelber RD, Goldhirsch A, Walley BA. Patient-reported outcomes with adjuvant 
exemestane versus tamoxifen in premenopausal women with early breast cancer undergoing ovarian suppression (TEXT and SOFT): a combined analysis of two phase 3 randomised trials. Lancet Oncol. 2015;16(7):848-58.

\section{Publisher's Note}

Springer Nature remains neutral with regard to jurisdictional claims in published maps and institutional affiliations.

Ready to submit your research? Choose BMC and benefit from:

- fast, convenient online submission

- thorough peer review by experienced researchers in your field

- rapid publication on acceptance

- support for research data, including large and complex data types

- gold Open Access which fosters wider collaboration and increased citations

- maximum visibility for your research: over $100 \mathrm{M}$ website views per year

At $\mathrm{BMC}$, research is always in progress.

Learn more biomedcentral.com/submissions 